\title{
The Role of External Audit in View of Sudden Financial Collapses on the Jordanian Commercial Banks Sector
}

\author{
Ayman Saleh Mustafa Harb ${ }^{1}$ \\ ${ }^{1}$ Department of Accounting, Faculty of Economics and Administrative Sciences, Zarqa University, Jordan \\ Correspondence: Dr. Ayman Saleh Mustafa Harb, Department of Accounting, Faculty of Economics and \\ Administrative Sciences, Zarqa University, Jordan.
}

Received: November 21, 2019

Accepted: December 24, 2019

Online Published: March 17, 2020

doi:10.5430/ijfr.v11n2p218

URL: https://doi.org/10.5430/ijfr.v11n2p218

\begin{abstract}
The study aims to determine the role of external audit in view of sudden financial collapse son Jordanian commercial banks. To achieve this, the researcher designed a questionnaire consists of (40) paragraphs.

The study results show that there is a statistically significant impact (the first hypothesis) of external audit on sudden financial collapses on Jordanian commercial banks. The value of the relationship between the two variables is 0.638 which is statistically significant, because calculated $\mathrm{f}$ value is equal to (75.31) which is statistically significant as (0.000) value, which is less than $(5 \%)$.

The study also indicates that there is a statistically significant effect (the second hypothesis) of external audit on the compliance of the audit profession rules on Jordanian commercial banks. The value of the relationship between the two variables is 0.615 which is statistically significant, because calculated $\mathrm{f}$ value is equal to (60.09) which is statistically significant as (0.000) value, which is less than $(5 \%)$.

The findings suggest that there is a statistically significant effect (the third hypothesis) of external audit on the detection of deception and fraud on Jordanian commercial banks. Where the value of the relationship between the two variables is (0.673) which is statistically significant, because calculated $\mathrm{f}$ value is equal to 91.07 which is statistically significant as (0.000) value, which is less than $(5 \%)$.
\end{abstract}

Keywords: external audit, sudden financial crises, commercial banks

\section{The General Framework of Study}

\subsection{Introduction}

In this modern era, with the latest developments, the acceleration of technology and modern technology, the expansion of economic, industrial, commercial and service projects, the weakness of accounting ethics, and despite the development of the profession of external audit. Surprisingly, a collapsing of many large companies in a sudden and rapid manner, due to the lack of professional commitment to the rules of the profession, and the existence of deception and fraud, so that money is more dominant than commitment to profession rules.

External audit which based on professional rules and professional commitment, reduces sudden failures, deception and fraud that occur in banks. The basis of the external audit profession is that there is no relationship between the bank and the external auditor, to commit to the audit profession away from the personal relationship.

\subsection{Problem of Study}

The problem of the study relates to the role of external audit in view of sudden financial collapses on Jordanian commercial banks, the impact of the external audit on preventing deception and fraud, and the auditor's compliance with the rules of the profession and the integrity of the financial statements.

\subsection{Research Questions}

The study will attempt to answer the following questions:

1. What is the impact of the external audit on the sudden financial collapses on Jordanian commercial banks?

2. What is the impact of the external audit on compliance with the rules of the audit profession on Jordanian commercial banks? 
3. What is the impact of the external audit on the detection of deception and fraud on Jordanian commercial banks? Importance of the study

With the expansion of companies and its branches internally and externally, the external audit profession has emerged to protect banks from sudden collapses, prevent deception and fraud, and maintain the rules and integrity of the external audit profession from any internal or external effect.

\subsection{Study Objectives}

This study aims to achieve a set of objectives, the most important of which are:

Determining the impact of the external audit on the sudden financial collapses on Jordanian commercial banks.

Determining the impact of external audit on compliance with auditing rules on Jordanian commercial banks.

Determining the impact of external audit on the detection of deception and fraud on Jordanian commercial banks.

\subsection{Study Hypotheses}

H1: There is no statistically significant impact of external audit on sudden financial collapses on Jordanian commercial banks.

$\mathrm{H} 2$ : There is no statistically significant impact of external audit on compliance with auditing rules on Jordanian commercial banks.

H3: There is no statistically significant impact of external audit on the detection of deception and fraud on Jordanian commercial banks.

\subsection{Variables}

This study used four variables. External audit as independent variable, and three dependent variables are represented in: (a) sudden financial collapses, (b) compliance with auditing rules, and (c) detection of deception and fraud.

\subsection{Research Design}

The following research design model describes the relationships among independent variable and dependent variables.

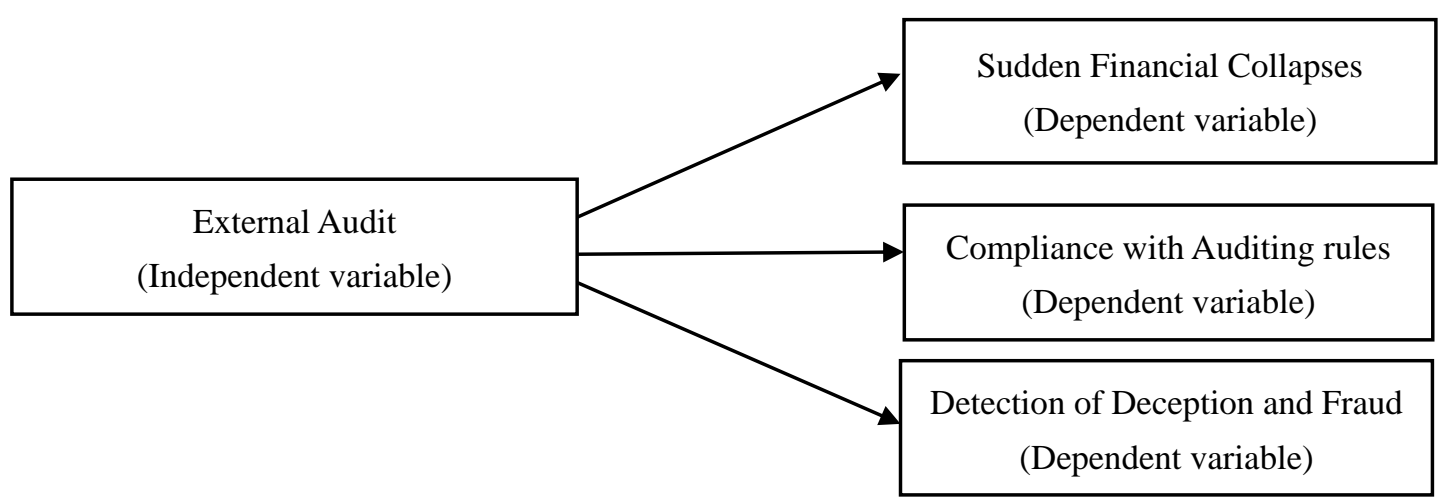

Figure 1. Research design model

\section{Literature Review}

The study of Ja'ara (2012), focused on the discovery of the most important methods and procedures used to identify deception and fraud in the financial statements of a group of public shareholding companies in Jordan. The main findings of this study are that the external auditors have the ability to detect techniques and methods of deception and fraud which are used in preparing financial reports. The main recommendations in this study are that the external auditor has to comply with international standards in the audit process and use of professional doubt in the risk of financial misrepresentation of the financial statements resulting from the illegal closure.

As reported by Egbunike, Amaechi Chinedu Egbunike, Francis Okafor, Gloria (2017), the company's management must work to control the internal control system and concealing any practices of deception and fraud by accounting department. The study identified the adequacy of the company's financial position and financial crises forecasting by 
determining the revised operational cash audit instrument. The main findings of this study are that the revised operational cash audit can be an effective tool for external auditor to gain accounting scams and accounting fraud.

Nawaish (2016), argued on the need for a set of controls, customs, ethical and professional principles to achieve confidence and credibility in the information contained in the financial statements, especially investors dealing in the stock market. The study concluded that there is a weakness in the performance of professional organizations in their role in monitoring the external auditor.

According to Kavrar, O Yılmaz, B (2017), there is an important relationship between the reliability of financial statements and their role in financial decision-making processes, and the identification of creative accounting methods used in data reliability. The study concluded that the discovery of errors and fraud is the responsibility of the auditor.

Kavrar \& Yilmaz (2017), there is strong relationship between corporate failures and auditors. Alaraji (2017). Conjugate the effect of corporate governance on the Expectation Gap between the external auditors and the users of the financial statements in the companies.

\subsection{Expected Contribution of the Present Study}

Most of the previous research has focused on the importance of external auditing in preventing deception and fraud in banks. The current study will be a new addition to the external audit on sudden financial collapses, linked to compliance with professional rules and deception and fraud detection.

\subsection{Theoretical Framework}

With the collapse of many banks and companies in the world, the interest in looking for a strong external audit system had been increased, which ensures the integrity of financial data from deception, fraud and perversion, to ensure the continuity of the bank. Many banks have undergone changes in the economy and its impact on profitability and continuity, because many of economic banks and auditing companies aim to achieve the financial goal away from the objectives of the profession.

According to Nicoletti (2016), the external audit is the collection and evaluation of evidences and proofs to determine their conformity with predetermined criteria, and the audit must be performed by a person of sufficient competence, experience and independence.

The researcher believes that the external audit is the examination and evaluation of data, financial and accounting statements to ensure that they are free from errors, negligence, deception or fraud, to access data, lists and financial statements of high reliability, can be relied on in the present and future.

Al-Dnibat (2012), defined compliance with the rules of the external audit profession as "the ethical basis upon which all companies and individuals are based".

The researcher believes that compliance with the rules of the audit profession is a set of ethical, religious, practical and scientific values in the performance of the audit profession.

\section{Methodology}

\subsection{Study Population and Sample}

The study population consists of Jordanian commercial banks by the end of 2018 and confined to Amman city. The study population includes (8) Jordanian commercial banks in Amman city, working in the field of industry, hotel and audit, to give the study flexibility in sample selection (study sample). The study sample consists of individuals working in Jordanian commercial banks $(115),(\mathrm{N}=115)$. The simple random sample of the study population includes (8) Jordanian commercial banks, limited to:

Table 1. The study population

\begin{tabular}{ll}
\hline Arab Bank & National Bank of Jordan \\
\hline Jordan Bank & Housing Bank for Trade and Finance \\
\hline Amman Cairo Bank & Jordan Arab Investment Bank \\
\hline Jordan Commercial Bank & Union Bank \\
\hline
\end{tabular}


The researcher used questionnaires as a research methodology. The participants of the study were employees working in Jordanian commercial banks, limited to managers and heads of commercial banks in Jordan, managers and heads of accounting departments, and internal audit departments. The reason for choosing those that the researcher believes that this category of employees is the subject of the study. Questionnaires are distributed to the following categories:

Table 2. The study sample

\begin{tabular}{ll}
\hline Financial Managers & Information technology departments \\
\hline The heads of accounting departments and accountants & Payable officers \\
\hline Heads and managers of commercial banks & Documentary Credit Officers \\
\hline Heads and managers of the Internal Audit Department & Loan Officers \\
\hline
\end{tabular}

The random sample was used to select the study sample. One hundred and fifteen questionnaires were distributed to the members of the sample. As for the study time period, it was at the end of $(31 / 12 / 2018)$.

\subsection{Type of Study}

This study is analytical and field descriptive, because it tests, analyzes and describes the role of external audit in view of sudden financial collapses on Jordanian commercial banks.

\subsection{Data Sources}

Data were collected from primary, secondary sources and personal experience of the researcher in the field of commercial banks in Jordan as follows:

A) Secondary sources: Of references, periodicals and previous studies, and annual reports issued by Jordanian commercial banks.

B) Primary sources: A questionnaire distributed to employees working in Jordanian commercial banks. The questionnaire addressed all research objectives, which were designed in the light of secondary data. Therefore, 115 questionnaires were distributed to individuals working in Jordanian commercial banks.

Number of distributed questionnaires $=115$

Number of returned questionnaires $=98$

Number of questionnaires that did not returned $=17$

The response rate is equal to $(98 / 115=85 \%)$

\section{Data Analysis}

For statistical analysis, the researcher used as statistical procedures in this study:

SPSS statistics software, Cronbach alpha, multiple linear regression analysis, Sample t-Test analysis.

A) Descriptive statistics include:

1. To demonstrate the importance of the questionnaires for the sample by using the mean. To show the extent of the agreement of sample members and to converge the responses by using the standard deviation.

2. Cronbach Alpha method for external consistency, and the percentage to indicate the degree of impact of these factors.

B) Inductive statistics in (T-Test), and multiple regression analysis.

C) SPSS statistics software.

Table 3 presents the results of the stability of the field of impact of the external audit on the sudden financial collapses on Jordanian commercial banks in the manner of (Cronbach Alpha) for external consistency: 
Table 3. Cronbach's Alpha testing

\begin{tabular}{lll}
\hline Questions & No. of Questions & Cronbach's alpha value \\
\hline Questions related to External Audit (Independent variable) & 10 & 0.868 \\
\hline Questions related to Sudden Financial Collapses (dependent variable) & 10 & 0.884 \\
\hline $\begin{array}{l}\text { Questions related to Compliance with Auditing rules (dependent } \\
\text { variable) }\end{array}$ & 10 & 0.801 \\
\hline $\begin{array}{l}\text { Questions related to Detection of Deception and Fraud (dependent } \\
\text { variable) }\end{array}$ & 10 & 0.774 \\
\hline Combined questions & 40 & 0.946 \\
\hline
\end{tabular}

Table 3 shows that the value of Cronbach's alpha ranged from (0.774 to 0.884$)$; this high value indicates a high consistency between the questions of the study, and indicates the high confidence of the study results. As for the value of Cronbach's alpha for combined questions, it was 0.946 , which is a high value.

\subsection{Descriptive Statistics}

Table 4 displays the means and standard deviations for the independent variable (external audit) fields and total mean calculated.

Table 4. Means and standard deviations for each external audit field and overall fields

\begin{tabular}{|c|c|c|c|c|c|c|}
\hline $\mathrm{NO}$ & External AuditFields & Mean & $\begin{array}{l}\text { Std. } \\
\text { Deviation }\end{array}$ & $\begin{array}{l}\text { Relative } \\
\text { Importance }\end{array}$ & $\begin{array}{l}\text { Agreement } \\
\text { Degree }\end{array}$ & Rank \\
\hline 7 & $\begin{array}{l}\text { The external auditor is interested } \\
\text { in purchasing invoices and selling } \\
\text { assets }\end{array}$ & 4.09 & 0.61 & 81.8 & high & 1 \\
\hline 10 & $\begin{array}{l}\text { The external auditor can disclose } \\
\text { the bank's profits by increasing or } \\
\text { decreasing without pressure from } \\
\text { the management }\end{array}$ & 4.07 & 0.68 & 81.4 & high & 2 \\
\hline 9 & $\begin{array}{l}\text { The performance of the external } \\
\text { auditor is based on the strength of } \\
\text { the opinion without any effect }\end{array}$ & 3.90 & 0.72 & 78.0 & high & 3 \\
\hline 1 & $\begin{array}{l}\text { Management is concerned with } \\
\text { external audit }\end{array}$ & 3.88 & 0.86 & 77.6 & high & 4 \\
\hline 8 & $\begin{array}{l}\text { The external auditor is interested } \\
\text { in short- and long-term } \\
\text { receivables }\end{array}$ & 3.86 & 0.67 & 77.2 & high & 5 \\
\hline 2 & $\begin{array}{l}\text { The external auditor Independent } \\
\text { from the bank's management }\end{array}$ & 3.78 & 0.76 & 75.6 & high & 6 \\
\hline 4 & $\begin{array}{l}\text { The Internal Auditor shall } \\
\text { cooperate with the External } \\
\text { Auditor }\end{array}$ & 3.75 & 0.72 & 75.0 & high & 7 \\
\hline 6 & $\begin{array}{l}\text { External auditors have sufficient } \\
\text { experience and appropriate } \\
\text { scientific and professional } \\
\text { qualifications }\end{array}$ & 3.72 & 0.81 & 74.7 & high & 8 \\
\hline 3 & $\begin{array}{l}\text { The management changes the } \\
\text { external auditor during the }\end{array}$ & 3.71 & 0.79 & 74.2 & high & 9 \\
\hline
\end{tabular}




\begin{tabular}{llllll}
\hline financial years & & & & & \\
\hline 5 & $\begin{array}{l}\text { Management provides the } \\
\text { required financial and accounting } \\
\text { data and information quickly }\end{array}$ & 3.71 & 0.88 & 74.2 & high \\
\hline External audit & 3.85 & 0.51 & 77.0 & high \\
\hline
\end{tabular}

Table 4 shows that the highest mean score of 4.09 for " The external auditor is interested in purchasing invoices and selling assets " has the highest agreement degree, and the lowest mean was (3.71) for " Management provides the required financial and accounting data and information quickly " and " The management changes the external auditor during the financial years" with a high agreement degree.

The total mean score is (3.85) for overall External audit fields with a high agreement degree.

Table 5 shows the calculated means and standard deviations of participants' responses for the first dependent variable "sudden financial collapses".

Table 5. Means and standard deviation for field "sudden financial collapses"

\begin{tabular}{|c|c|c|c|c|c|c|}
\hline $\mathrm{NO}$ & Sudden Financial Collapses Fields & Mean & $\begin{array}{l}\text { Std. } \\
\text { Deviation }\end{array}$ & $\begin{array}{l}\text { Relative } \\
\text { Importance }\end{array}$ & $\begin{array}{l}\text { Agreement } \\
\text { Degree }\end{array}$ & rank \\
\hline 4 & $\begin{array}{l}\text { Taking lessons from sudden collapses } \\
\text { of banks by bank's management }\end{array}$ & 4.18 & 0.80 & 83.6 & high & 1 \\
\hline 6 & $\begin{array}{l}\text { Management interests in following } \\
\text { risks related to the Bank }\end{array}$ & 4.14 & 0.83 & 82.8 & high & 2 \\
\hline 3 & $\begin{array}{l}\text { The selection of external and internal } \\
\text { auditors by management shall be based } \\
\text { on scientific and practical basis }\end{array}$ & 4.13 & 0.71 & 82.6 & high & 3 \\
\hline 5 & $\begin{array}{l}\text { The management shall separate the } \\
\text { tasks and duties of the Bank's } \\
\text { employees }\end{array}$ & 4.12 & 0.88 & 82.4 & high & 4 \\
\hline 2 & $\begin{array}{l}\text { The management maintains the } \\
\text { continuity of the Bank }\end{array}$ & 4.11 & 0.83 & 82.2 & high & 5 \\
\hline 8 & $\begin{array}{l}\text { Management Selects Employees with } \\
\text { specialized certificates in the Bank's } \\
\text { business areas }\end{array}$ & 3.94 & 0.82 & 78.8 & high & 6 \\
\hline 10 & $\begin{array}{l}\text { Management provides adequate } \\
\text { financial reporting on the Bank's } \\
\text { position }\end{array}$ & 3.94 & 0.84 & 78.8 & high & 7 \\
\hline 7 & $\begin{array}{l}\text { Management concerns with adequate } \\
\text { methods of protection for the Bank } \\
\text { (records, assets, cash) }\end{array}$ & 3.93 & 0.77 & 78.6 & high & 8 \\
\hline 1 & $\begin{array}{l}\text { The management concerns to ensure } \\
\text { adequate disclosure of financial } \\
\text { statements and reports }\end{array}$ & 3.81 & 0.92 & 76.2 & high & 9 \\
\hline 9 & $\begin{array}{l}\text { The Bank holds training courses for its } \\
\text { employees }\end{array}$ & 3.57 & 0.99 & 71.4 & high & 10 \\
\hline Sudc & a financial collapses & 3.99 & 0.59 & 79.8 & high & \\
\hline
\end{tabular}

Table 5 shows that mean scores range from 3.57 to 4.18. The highest mean score was for "Taking lessons from sudden collapses of banks by bank's management" (4.18). Followed by "Management interests in following risks 
related to the Bank" (4.14), and the lowest mean was for "The Bank holds training courses for its employees" (3.57). These items were in the high agreement degree. The total mean for "Sudden financial collapses" reached (3.99), which indicates a high agreement degree.

Table 6 shows the calculated means and standard deviations of participants' responses for the second dependent variable "compliance with the rules of the audit profession".

Table 6. Means and standard deviations for field "compliance with the rules of the audit profession"

\begin{tabular}{|c|c|c|c|c|c|c|}
\hline $\mathrm{NO}$ & $\begin{array}{l}\text { Compliance with the Rules of the } \\
\text { Audit Profession Fields }\end{array}$ & Mean & $\begin{array}{l}\text { Std. } \\
\text { Deviation }\end{array}$ & $\begin{array}{l}\text { Relative } \\
\text { Importance }\end{array}$ & $\begin{array}{l}\text { Agreement } \\
\text { Degree }\end{array}$ & Rank \\
\hline 10 & $\begin{array}{l}\text { Not allowing for the management } \\
\text { to influence the external auditor's } \\
\text { work by reservation the bank's } \\
\text { data and financial statements }\end{array}$ & 3.95 & 0.72 & 79.00 & high & 1 \\
\hline 4 & $\begin{array}{l}\text { Commitment to audit profession's } \\
\text { ethics }\end{array}$ & 3.89 & 0.87 & 77.8 & high & 2 \\
\hline 6 & $\begin{array}{l}\text { Commitment } \text { to applying } \\
\text { information } \\
\text { financial and accounting } \\
\text { statements }\end{array}$ & 3.88 & 0.89 & 77.6 & high & 3 \\
\hline 2 & $\begin{array}{l}\text { Management concerns in } \\
\text { formation of audit committees }\end{array}$ & 3.87 & 0.85 & 77.4 & high & 4 \\
\hline 9 & $\begin{array}{l}\text { Commitment of audit workers in } \\
\text { loyalty to the audit profession }\end{array}$ & 3.85 & 0.84 & 77.00 & high & 5 \\
\hline 5 & $\begin{array}{l}\text { Commitment to the } \\
\text { confidentiality of the Bank's } \\
\text { financial information and data }\end{array}$ & 3.81 & 0.88 & 76.20 & high & 6 \\
\hline 3 & $\begin{array}{l}\text { Compliance an international audit } \\
\text { standards }\end{array}$ & 3.80 & 0.80 & 76.00 & high & 7 \\
\hline 7 & $\begin{array}{l}\text { Compliance with periodic reviews } \\
\text { of financial and accounting data }\end{array}$ & 3.77 & 0.92 & 75.40 & high & 8 \\
\hline 1 & $\begin{array}{l}\text { The management selects the audit } \\
\text { firm that complies with the rules } \\
\text { of the audit profession }\end{array}$ & 3.76 & 0.76 & 75.20 & high & 9 \\
\hline 8 & $\begin{array}{l}\text { Commitment to conservative } \\
\text { accounting in profits' forecasting }\end{array}$ & 3.76 & 0.92 & 75.20 & high & 10 \\
\hline Com & nitment with auditing rules & 3.83 & 0.65 & 76.6 & high & \\
\hline
\end{tabular}

Table 6 shows that mean scores range from 3.76 to 3.95. The highest mean score was for " Not allowing for the management to influence the external auditor's work by reservation the bank's data and financial statements " (3.95), followed by "Commitment to audit profession's ethics" (3.89), and the lowest mean was for "Commitment to conservative accounting in profits' forecasting" (3.76).These items are in the high agreement degree. The total mean for" Commitment with auditing rules" reached (3.83), which indicates that the level of Commitment with auditing rules in various commercial banks in Jordan is high.

Table 7 shows the calculated means and standard deviations of participants' responses for the third dependent variable "detection of deception and fraud". 
Table 7. Means and standard deviations for field" detection of deception and fraud"

\begin{tabular}{|c|c|c|c|c|c|c|}
\hline NO & $\begin{array}{l}\text { Detection of Deception and Fraud } \\
\text { Fields }\end{array}$ & Mean & $\begin{array}{l}\text { Std. } \\
\text { Deviation }\end{array}$ & $\begin{array}{l}\text { Relative } \\
\text { Importance }\end{array}$ & $\begin{array}{l}\text { Agreement } \\
\text { Degree }\end{array}$ & Rank \\
\hline 7 & $\begin{array}{l}\text { Management's lack of interest in } \\
\text { Bank's staff opinions }\end{array}$ & 3.91 & 0.61 & 78.2 & high & 1 \\
\hline 1 & $\begin{array}{l}\text { The strength and weakness of the } \\
\text { external auditor in detecting of } \\
\text { deception and fraud }\end{array}$ & 3.85 & 0.83 & 77.0 & high & 2 \\
\hline 10 & $\begin{array}{l}\text { Neglecting the institutional } \\
\text { governance of the bank }\end{array}$ & 3.84 & 0.73 & 76.8 & high & 3 \\
\hline 9 & $\begin{array}{l}\text { Weakness of internal control } \\
\text { methods in the bank }\end{array}$ & 3.75 & 0.74 & 75.0 & high & 4 \\
\hline 2 & $\begin{array}{l}\text { Bank's violation of laws and rules of } \\
\text { audit profession and international } \\
\text { accounting standards }\end{array}$ & 3.73 & 0.76 & 74.6 & high & 5 \\
\hline 8 & $\begin{array}{l}\text { Management's interest in profits } \\
\text { only to satisfy shareholders }\end{array}$ & 3.72 & 0.65 & 74.4 & high & 6 \\
\hline 6 & Failure to choose external audit firm & 3.60 & 0.78 & 72.0 & high & 7 \\
\hline 4 & $\begin{array}{l}\text { Frequent disputes between external } \\
\text { auditors and management to } \\
\text { manipulate audit reports }\end{array}$ & 3.58 & 0.64 & 71.6 & high & 8 \\
\hline 3 & $\begin{array}{l}\text { Management's effect on employees } \\
\text { in financial departments and sections }\end{array}$ & 3.57 & 0.73 & 71.4 & high & 9 \\
\hline 5 & $\begin{array}{l}\text { External auditors are unable to } \\
\text { obtain the required information due } \\
\text { to pressure from the management }\end{array}$ & 3.56 & 0.82 & 71.4 & high & 10 \\
\hline detec & ion of deception and fraud & 3.71 & 0.42 & 74.2 & high & \\
\hline
\end{tabular}

Table 7 shows that mean scores range from 3.56 to 3.91. The highest mean score was for "Management's lack of interest in Bank's staff opinions" (3.91), followed by "The strength and weakness of the external auditor in detecting of deception and fraud" (3.85), and the lowest mean was for "External auditors are unable to obtain the required information due to pressure from the management" (3.56). These items are in the high agreement degree. The total means score for "detection of deception and fraud" reached (3.71) with the high agreement degree.

\section{Results by Studying Hypotheses}

\subsection{First Hypothesis}

$\mathrm{H}_{0}$ : There is no statistically significant impact of external audit on sudden financial collapses on Jordanian commercial banks.

$\mathrm{H}_{1}$ : There is statistically significant impact of external audit on sudden financial collapses on Jordanian commercial banks.

To test this hypothesis, simple linear regression analysis was used (Table 8).

Table 8. Simple linear regression analysis results

\begin{tabular}{lllllllll}
\hline Independent variable & $\mathbf{r}$ & $\mathbf{R}^{2}$ & $\mathbf{f}$ & Sig f & $\mathbf{B}$ & $\boldsymbol{\beta}$ & $\mathbf{t}$ & Sig t \\
\hline External Audit & 0.638 & 0.406 & 75.31 & 0.000 & 1.649 & 0.551 & 6.67 & $0.000^{*}$ \\
\hline
\end{tabular}


1. The correlation coefficients ( $\mathrm{r}$ ) between the external audit and sudden financial collapses on the Jordanian commercial banks was (0.638), R- Square value (0.406), F value (75.31) at significance (0.000). All these findings implied that there was a positive statistically significant relationship at a significant level $(\mathrm{P} \leq 0.05)$ between the external audit and sudden financial collapses on the Jordanian commercial banks.

2. The value of the $(\beta)$ coefficient of the external audit effect on the sudden financial collapses on Jordanian commercial banks in the regression model reached (0.551).

3. The $(t)$ value determines the significance of each independent variable and beta coefficients are used to determine the extent of prediction for each independent variable. And since the values of the absolute significance level $(0.000)$ for the external audit were less than (5\%), values of coefficients are significant in the Regression model.

4. The value of $\mathrm{R}^{2}$ indicates the percentage variation in the dependent variable, which can be predicted by the independent variable. This ratio is $40.6 \%$. This indicates the independent variable's ability to predict the dependent variable.

5. The first null hypothesis was rejected, and the alternative hypothesis "There is statistically significant impact of external audit on sudden financial collapses on Jordanian commercial banks" was accepted.

\subsection{Second Hypothesis}

$\mathrm{H}_{0}$ : There is no statistically significant effect of the external audit on compliance with auditing rules on Jordanian commercial banks.

$\mathrm{H}_{1}$ : There is a statistically significant effect of the external audit on compliance with auditing rules on Jordanian commercial banks.

The simple linear regression analysis was used to test this hypothesis (Table 9):

Table 9. Simple linear regression analysis results

\begin{tabular}{lllllllll}
\hline Independent variable & $\mathbf{r}$ & $\mathbf{R}^{\mathbf{2}}$ & $\mathbf{f}$ & $\mathbf{S i g} \mathbf{f}$ & $\mathbf{B}$ & $\boldsymbol{\beta}$ & $\mathbf{t}$ & Sig t \\
\hline External Audit & 0.615 & 0.378 & 66.85 & 0.000 & 1.995 & 0.483 & 8.17 & $0.000^{*}$ \\
\hline
\end{tabular}

1. The correlation coefficients (r) between the external audit and compliance with the auditing rules of the Jordanian commercial banks was (0.615), R- Square value (0.378), F value (66.85) at significance (0.000). All these findings implied that there was a positive statistically significant relationship at a significant level $(\mathrm{P} \leq 0.05)$ between the external audit and compliance with the auditing rules of the audit profession on the Jordanian commercial banks.

2 . The value of the $(\beta)$ coefficient of the external audit effect on compliance with the auditing rules of the audit profession on the Jordanian commercial banks in the regression model reached (0.483).

3. The value of the $(\beta)$ coefficient of the external audit effect on compliance with the auditing rules of the audit profession on the Jordanian commercial banks in the regression model reached (0.483).

4. The value of $\left(\mathrm{R}^{2}\right)$ indicates the percentage variation in the dependent variable, which can be predicted by the independent variable. This ratio is $37.8 \%$. This indicates the independent variable's ability to predict the dependent variable.

5. The second null hypothesis was rejected, and the alternative hypothesis "There is a statistically significant effect of the external audit on compliance with auditing rules on Jordanian commercial banks "was accepted.

\subsection{Third Hypothesis}

$\mathrm{H}_{0}$ : There is no statistically significant impact of external audit on the detection of deception and fraud on Jordanian commercial banks.

$\mathrm{H}_{1}$ : There is a statistically significant impact of external audit on the detection of deception and fraud on Jordanian commercial banks.

The simple regression analysis was used to test this hypothesis (Table 10). 
Table 10. Simple linear regression analysis results

\begin{tabular}{lllllllll}
\hline Independent variable & $\mathbf{r}$ & $\mathbf{R}^{\mathbf{2}}$ & $\mathbf{f}$ & Sig f & $\mathbf{B}$ & $\boldsymbol{\beta}$ & $\mathbf{t}$ & Sig t \\
\hline External Audit & 0.673 & 0.453 & 91.07 & 0.000 & 0.819 & 0.815 & 9.54 & $0.000^{*}$ \\
\hline
\end{tabular}

1. The correlation coefficients (r) between the external audit and the detection of deception and fraud on Jordanian commercial banks was (0.673), R- Square value (0.453), F value (91.07) at significance (0.000). All these findings implied that there was a positive statistically significant relationship at a significant level $(\mathrm{P} \leq 0.05)$ between the external audit and the detection of deception and fraud on Jordanian commercial banks.

2. The value of the $(\beta)$ coefficient of the external audit effect on the detection of deception and fraud on Jordanian commercial banks in the regression model reached $(0.815)$.

3. The ( $\mathrm{t}$ ) value determines the significance of each independent variable and beta coefficients are used to determine the extent of prediction for each independent variable. And since the values of the absolute significance level (0.000) for the external audit were less than (5\%), values of coefficients are significant in the Regression model.

4. The value of (R2) indicates the percentage variation in the dependent variable, which can be predicted by the independent variable. This ratio is $45.3 \%$. This indicates the independent variable's ability to predict the dependent variable.

5. The third null hypothesis was rejected, and the alternative hypothesis "There is a statistically significant effect of the external audit on the detection of deception and fraud on Jordanian commercial banks "was accepted.

\section{Research Limits}

One of the most important problems facing the researcher was the difficulty of obtaining the financial data for the commercial banks that collapsed in Jordan.

\section{Conclusion}

1. The first null hypothesis was rejected, and the alternative hypothesis "There is statistically significant impact of external audit on sudden financial collapses on Jordanian commercial banks" was accepted.

2. The second null hypothesis was rejected, and the alternative hypothesis "There is a statistically significant effect of the external audit on compliance with auditing rules on Jordanian commercial banks "was accepted.

3. The third null hypothesis was rejected, and the alternative hypothesis "There is a statistically significant effect of the external audit on the detection of deception and fraud on Jordanian commercial banks "was accepted.

\subsection{Recommendations}

Depending on the findings, the researcher suggests the following recommendations:

1. The results were positive and should be strengthened to maintain the credibility and accuracy of information, financial and accounting data, and increase attention to external audit.

2. Commercial banks require changing the audit firms in each financial period, to enhance confidence in issued reports.

3. Attention to the topic of external auditing in academic and educational departments, and explaining the importance of external auditing in the integrity of financial statements submitted by banks, and the development of other studies in areas other than banking to enhance confidence in the importance of the external auditor to open up avenues for all business sectors.

\section{References}

Alaraji, F. (2017). The Role and Impact of Corporate Governance on Narrowing the Expectations Gap between the External Auditor and the Financial Community (A Practical Study of a Sample of External Audit Offices and Companies Invested in Iraq) (Case Study in Iraq). American Scientific Research Journal for Engineering, Technology, and Sciences (ASRJETS). Retrieved from file:///C:/Users/3433/Downloads/3183-Article\%20Text-9542-1-10-20170716\%20(2).pdf

Al-Dnibat, A. (2012). Auditing in the light of international standards (4th ed.). Dar Wael Publishing, Amman, Jordan. 
Egbunike, A. C. E., \& Francis Okafor, G. (2017). Audit Firm Attributes and Bank Failures in Nnamdi Azikiwe University, Awka. Nnamdi Azikiwe University, Awka - Nnamdi Azikiwe University, Awka. Retrieved from https://www.researchgate.net/publication/324598407_Audit_Firm_Attributes_and_Bank_Failures_in_Nigeria

Jafara, O. (2012). Methods of the External Auditor in the Detection of Fraud / Fraud in the Financial Statements of Public Shareholding Companies - Survey Study in the External Audit Offices in Jordan. Accounting Department, Amman, Jordan. Retrieved from https://journals.ju.edu.jo/DirasatAdm/article/view/3410

Kavrar, O., \& Y1lmaz, B. (2017). Corporate Collapses in Australia: Case of Harris Scarfe. Journal of Economics, Business and Management, 5(1). https://doi.org/10.18178/joebm.2017.5.1.477

Nawaish, M. E. (2016). Impact of External Audit Quality on Earnings Management by Banking Firms: Evidence from Jordan. Zaytoonah University of Jordan. https://doi.org/10.9734/BJAST/2016/19796

Nicoletti, A. (2016). The Effects of Auditors and Regulators on Bank Financial Reporting: Evidence from Loan Loss $\begin{array}{lllll}\text { Provisions. Ohio State University, USA. } & \text { Retrieved }\end{array}$ https://etd.ohiolink.edu/!etd.send_file?accession=osu1468571167\&disposition=inline 